\title{
Spooky Birds and Origin of Life: A Quantum Mechanics Description of Bird Migration
}

\author{
H. Hossieni*, J. M. A. Fatah \\ Department of Physics, College of Science, University of Sulaimani, Iraqi-Kurdistan
}

Submitted: 9 July 2018. Revised: 28 December 2018. Accepted: 1 January 2019

\begin{abstract}
In this work we explain a strange quantum phenomenon in biology that the European Robin uses to navigate. The bird's brain contains a chemical called cryptochromes which has two of its electrons entangled through collision with photons. These two electrons hop between singlet and triplet states. This hopping is sensitive to the earth's magnetic field causing different signals to be transferred to its brain. It is believed that these birds use quantum entanglement for their navigations. We also discuss the importance of this phenomenon in trying to find the origin of life. We also explain the view of some who believe that quantum field is well entrenched in the origin of life and that we have to look for a quantum self-replicator that can repeat itself.
\end{abstract}

\begin{abstract}
ABSTRAK
Hasil penelitian ini mencoba menjelaskan fenomena kuantum yang aneh pada ranah biologi dimana burung robin eropa bernavigasi menggunakannya. Otak burung tersebut mengandung material kimia yang disebut dengan cryptochromes yang mempunyai dua buah elektron yang terjebak dalam pengaruh interaksi tumbukan antara elektron tersebut dengan foton. Dua elektron tersebut melompat di antara keadaan singlet dan triplet. Lompatan ini dipengaruhi oleh medan magnetik bumi yang memberikan sinyal berbeda-beda untuk ditransfer ke otaknya. Burung-burung ini diyakini menggunakan prinsip pengaruh kuantum untuk navigasinya. Kami juga mengungkap pentingnya fenomena ini dalam usaha mencari asal mula kehidupan. Kami juga menjelaskan sudut pandang yang mempercayai bahwa medan kuantum diyakini berperan penting dalam penjelasan tentang asal mula kehidupan dan bahwa kita harus mencari tahu tentang pembelahan materi dengan pengaruh kuantum yang dapat berlangsung berulang-ulang dengan sendirinya.
\end{abstract}

Keywords: Cryptochromes; Decoherency; Entanglement; Life

\section{INTRODUCTION}

The migration of birds from south hemisphere to the north and vice versa is still unanswered question in science. Scientists in the nineteenth century assumed that earth's magnetic field should have central role in the process (R. Wiltschko \& W. Wiltschko, 2014). In addition to birds, other animals like marine turtles and bats find their directions by using the same magnetic field (Holland, Thorup, Vonhof, Cochran \& Wikelski, 2006; Alerstam, 2006). Even Canadian monarch butterflies use, in their long trip to Mexico, the Earth's magnetic field as a guide (Urquhart, 1976). One could easily ask: what mechanism do these animals

*Correspondence Address:

Sulaymaniyah, Kurdistan Region, Iraq

E-mail: hossien.hossieni@univsul.edu.iq use to detect the weak magnetic field of the earth. It seems as if these creatures carry and use compasses in their navigations. However, there are unanswered questions like: how this instrument works and how messages reach to the brain. These questions are still hot issues in science.

One of the birds that uses the magnetic field of the earth, as a guide, is the European Robin. It has been assumed that these birds use a special technique to find their directions in migration. This technique is based on one of the most complicated and controversial topic in physics, namely, the quantum entanglement (Davies, 2009).

Quantum theorists have come up with a new discipline called quantum biology. They believe that this might lead them to solve the intractable problem of the origin of life. To this 
end, physicists use the most effective tool they have, i.e., quantum mechanics. Scientists believe that if life is regarded as a tree, then its roots are in quantum world while its trunk and foliage are in normal or classical world (Al-Khalili \& McFadden, 2008).

A physicist who wishes to unravel the mystery of the origin of life has to work on a quantum system. In doing so, she or he will encounter a big problem, namely, any contact with the system will cause it to convert to a classical one in a very short time (Schlosshauer, 2005).

Physicists try to work on biological systems that are related to quantum mechanics to find a system with a slightly longer time. The European Robins have a quantum mechanical system in their eyes that they use to navigate (Ritz, 2011). Although this interacts with outside but the related decoherence time is somehow longer (Biskup et al., 2009).

In the next section, we cast some light on quantum mechanics and decoherence problem in those systems. Then we explain the mechanism that the European Robins use in their eyes.

\section{METHOD}

A quantum system has certain properties that a classical system does not have. Nearly, everything we sense in our normal daily life belong to the framework of the classical systems. These phenomena are governed by classical laws. For example, the three laws of Newton, Maxwell's electromagnetic laws, and thermodynamics laws are all classical ones. But in a microscopic world, the world of atoms and molecules, these laws lose their accuracy and precision. In this world, there exists another set of rules that are strange to our classical way of thinking. Duality is a good example of this. This term means that when you want to measure the particle properties of an electron (or any other elementary particle), then it behaves like a particle. When you, on the other hand, want to measure its wave properties, then it will behave as a wave. These two properties cannot appear simultaneously (Schmid, Krzywicki, Squires, \& Cutkosky, 1970).

An isolated quantum system may exist in several states. Each state has certain probability. This constitutes the definition of superposition of the states. When we perform a measurement on a system, then we can say something about the state of the system using the probability language. Every state is repre- sented by a wave function. These wave functions have a coherency relationship among themselves which implies that the difference in phases of these waves is constant. When a measurement is carried out on a quantum system, it localizes itself into a state then transforms into a classical system. The time it takes for this transformation to happen is known as decoherence time. It is only after such a time that the indeterminacy eases and the coherency disappear (Zurek, 2003).

One of the properties of any elementary particle is spin. It can be imagined as a rotation of such particle around its imaginary axis. Spin lacks its counterpart in our normal world. An electron is known to have a spin of $1 / 2$ which means that it has to complete two rotations to go back to its initial state. In a quantum mechanical system, such as an atom, if there are two electrons having the same energy state then they must spin in opposite directions. This is because of the Pauli Exclusion Principle. Classically, this means that if one of the electrons rotates in clockwise direction then the other must rotate in anticlockwise direction. If, for any reason, the spin direction of one of them changes then this change will be transferred instantaneously to the other electron. In this sense the two electrons are entangled and the transferred information between them is known as spooky action in a distance.
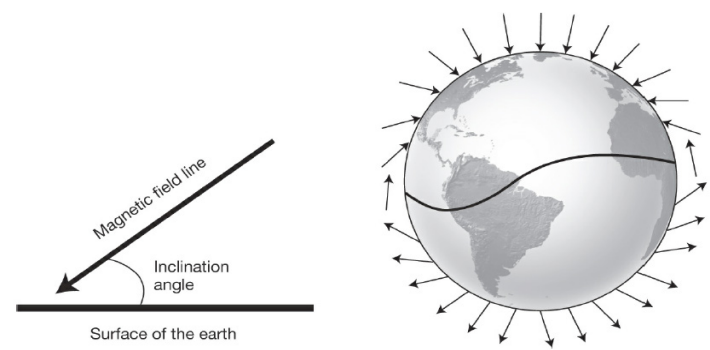

Figure 1. Bending of earth magnetic field by geographical point (McFadden \& Al-Khalili, 2014).

Because transferring information between the electrons occurs simultaneously then one can say that it violates the special theory of relativity. According to this theory, the speed of this transfer is limited by the speed of light. This notion of instant information transfer cannot find its place in classical world. However, some believe that it violates the spirit of relativity theory (Hossieni, Fatah, Kaki \& Kamal, 2017; Aczel, 2002).

This quantum phenomenon exists in reality and can be verified in the laboratory. But 
there were scientists, like Einstein, who were critical of quantum mechanics in the first place.

\section{RESULT AND DISCUSSION}

We mentioned earlier that studies in the twentieth century have shown that birds, such as the European Robin, can sense the Earth's magnetic field in their navigations (Vlatko, 2011). These studies have created a great deal of interest among physicists. We know that compass's direction changes with the latitude and make an angle that depends on geographical points Figure 1.

There is a protein in the European robin's eye called cryptochromes which gets stimulated by light (Partch \& Sancar, 2005). As a consequence, an electron is transferred from one molecule to another causing the molecules to gain a net charge. These charged molecules are commonly known as free radicals. Each molecule carries an extra electron and because they are formed simultaneously then their spins are correlated, i.e., they become entangled. These two electron spins make a coherence system on which a weak magnetic field can have influence. Then the interactions caused by chemical activities of free radicals are transferred via signals to the brain.

Figure 2 shows a physical model for the above system. It consists of two electrons and a nucleon. The spins of electrons and the nucleon are $1 / 2$. The electrons can only be in one of the two states. A singlet state with a total spin of zero and a triplet state having a total spin of one.

There are three directions in the triplet state while there is only one direction - zero direction- in the singlet one. The pair of radicals performs one million full quantum mechanical complicated oscillations. This can be attributed to the quantum coherence between the spins of the two electrons. The electrons are coherent and interact locally with other radicals. Although both states have the same initial energy, a weak magnetic field like that of the Earth can change their oscillation time and influence their hopping.

As the external magnetic field influences the singlet-triplet hopping, the chemical production of one the states becomes more than the other. The change in Earth's magnetic field (inclination angle in Figure 1) causes different chemical productions and these are transferred to the brain which enable the bird to find its way (Lambert, Chen, Cheng, Li, Chen, \& Nori,
2013)

This phenomenon is interesting for another reason. One of the purposes of quantum biology, as we mentioned earlier, is to search for the origin of life. For instance to find the first self-replicator, that the scientists believe, should be a quantum mechanical system (Davies, 2004). When an observer interacts with a quantum system, the latter converts itself, in a very short time, into a classical one. And in the process, we lose the very problem we tried to search for in the first place. The quantum mechanical system in the bird's eye is relatively too slow to react (in the order of a microsecond) (Biskup et al., 2009). This is a large number in comparison to other quantum systems and one would hope that this may become a way to increase decoherence time in quantum mechanical systems.

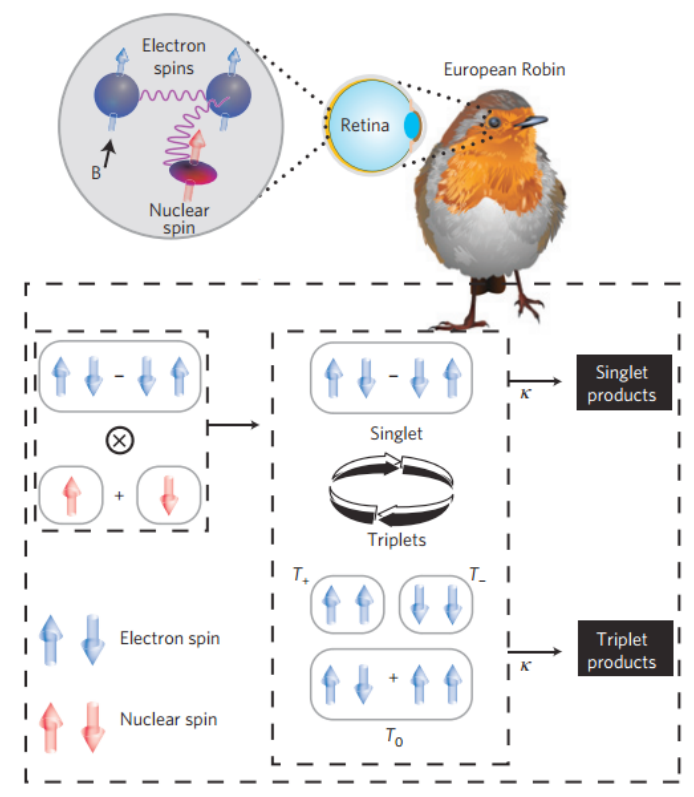

Figure 2. Entanglement mechanism in Robin's eye (Lambert, N., Chen, Y-N., Cheng, Y-C, Li, C-M., Chen, G-Y. \& Nori, F., 2013).

\section{CONCLUSION}

We have described, in this work, a very interesting quantum phenomenon which is believed to be used by the European robin to find direction of navigation. There is a quantum system in the eye of that bird, which is largely stable and has minimal interaction with the outside chaotic environment. Another main problem in quantum biology is related to origin of life. New ideas suggest that the primordial life has begun in a quantum system. In this sense, 
there might be quantum beings that are repeated. The main problem in the search to find self-replicators in quantum mechanics is that these systems collapse to a classical one in a very short time. It may be possible to suggest that this bird's eye can be regarded as an example of a proper quantum system to find a self-replicator.

\section{REFERENCES}

Aczel, D. A. (2002). Entanglemet: The Greatest Mystery in Physics. New York : Four Walls Eight Windows.

Alerstam, T. (2006), Conflicting Evidence about Long-Distance Animal Navigation. Science. 313 (5788), 791-794. doi: 10. 1126/science. 1129048.

Al-Khalili, J., \& McFadden, J. (2008). Quantum Coherence and the Search for the First Replicator. In Abbott, Davies P. C. W., Pati A. K., Quantum Aspects of life, (pp. 33-49), London: Imperial College press.

Biskup T., Schleicher E., Okafuji, A., Link G., Hitomi, K., Getzoff E. D., \& Weber, S. (2009). Direct Observation of a Photoinduced Radical Pair in a Cryptochrome Blue-Light Photoreceptor, Chem. Int. Ed., 48, 404.

Davies p. (2009). The quantum life, Phys. World, 22(7), 24. doi: 10.1088/2058-7058/22/07/37.

Partch, C. L. \& Sancar, A. (2005). Photochemistry and Photobiology of Cryptochrome Blue-light Photopigments: The Search for a Photocycle. Photochemistry and Photobiology. 81: 1291-1304, doi:10.1562/2005-07-08-IR-607.

Davies, P. C. W. (2004). Does quantum mechanics play a non-trivial role in life? Biosystems. 78(1-3), 69-79. Or doi: 10. 1016/j. biosystems. 2004. 07. 001.
Holland, R. A, Thorup, K., Vonhof, M. J., Cochran, W. W. \& Wikelski, M.(2006). Navigation: Bat orientation using Earth's magnetic field. Nature. 444(7120), 702. Or doi: 10. 1038/444702a.

Hossieni, H., Fatah, J. M. A., Kaki S. \& Kamal, K. (2017). From Quintessence to Spookiness Evolution of Supernatural in Physicist Mind. EJST. 13(1),117-125.

Lambert, N., Chen, Y-N., Cheng, Y-C, Li, C-M., Chen, G-Y. \& Nori, F. (2013). Quantum biology. Nat Phys. 9, 10-18, doi: 10. 1038/nphys2474.

McFadden J., \& Al-Khalili, J. (2014). Life on the Edge The Coming of Age of Quantum Biology. New York: CROWN PUBLISHERS.

Ritz, T. (2011). Quantum effects in biology: Bird navigation. Procedia Chemistry. 3(1), 262-275. Or doi: 10.1016/j.proche.2011.08.034.

Schlosshauer, M. (2005). Decoherence, the measurement problem, and interpretations of quantum mechanics. Rev. Mod. Phys. 76, 1267. Or doi: 10. 1103/RevModPhys. 76. 1267.

Schmid, C., Krzywicki, A., Squires, E., \& Cutkosky, R. (1970). What is Duality? [and Discussion]. Proceedings of the Royal Society of London. Series A. Mathematical and Physical Sciences. 318(1534), 257-278. Retrieved from http://www.jstor.org/stable/77607.

Urquhart, F. A. (1976). Found at last-monarchs winter home. Nat. Geogr. 150, 160-173.

Vlatko, V. (2011). Living in a Quantum World. Scientific American. 304, 38 - 43. Or doi: 10.1038/ scientificamerican0611-38.

Wiltschko,R., \& Wiltschko, W. (2014). Magnetoreception, BioEssays, 28(2),105-228.

Zurek,W. H.(2003). Decoherence, einselection, and the quantum origins of the classical. Rev. Mod. Phys. 75, 715. Or doi:10.1103/RevModPhys.75.715. 